Rev. Latinoam. Psicopat. Fund., São Paulo, v. 14, n. 2, p. 219-221, junho 2011

\title{
Editorial
}

\section{Ainda podemos pensar?}

Manoel Tosta Berlinck

O Editorial publicado na Revista Latinoamericana de Psicopatologia Fundamental de março de 2011 merece alguns comentários.

O artigo de Vannevar Bush, "As we may think", vindo a público originalmente na revista Monthly Review de julho de 1945, anuncia uma situação que se realizou plenamente com os fantásticos avanços tecnológicos ocorridos depois da Segunda Guerra Mundial; a fabricação em massa de computadores pessoais (PCs) e a internet.

Dispomos, hoje, de uma gigantesca quantidade de informações espalhadas na internet e possuímos uma capacidade de comunicação absolutamente inimaginável até os anos 90 do século passado. Bush acreditava que essas condições aumentariam a capacidade de pensamento entendida como a prática de associação entre fenômenos e artefatos separados e distantes. O comentário feito pelo prof. dr. Carlos Henrique de Brito Cruz, na introdução ao texto de Bush, explicita essa concepção do pensar: a capacidade do humano em associar aquilo que se encontra disponível, mas separado na realidade, mesmo que virtual.

Entretanto, a psicanálise ensina que a capacidade de associação do humano, ou seja, a capacidade de pensar, é limitada por razões intrínsecas e extrínsecas ao próprio humano. 
Tal limitação ocorre, segundo Freud, graças ao princípio do prazer, ou seja, à capacidade de se evitar o desprazer. Tudo indica que o desprazer é um estado no qual forças internas e externas provocam sofrimento no humano e este busca, na repetição, estado de prazer.

A principal meta de qualquer tratamento psicanalítico é a livre associação. A regra da livre associação, devendo ser explicitada e aceita no início de cada tratamento, é o almejado tanto pelo clínico quanto pelo paciente. Entretanto, nessa busca, os dois se deparam muito rapidamente com aquilo denominado resistência, ou seja, a incapacidade do paciente (e, muitas vezes, do clínico) em livre associar. A resistência se manifesta como uma notável compulsão à repetição. A fala do paciente, no tratamento, torna-se repetitiva, padronizada, estereotipada e, principalmente, aborrecida. Ela se manifesta concretamente e dificulta (e até impede) a livre associação tanto do psicanalista quanto a sua própria. O psicanalista, por sua vez, escuta (escutar é muito diferente de ouvir) a fala do paciente em busca de algo que lhe permita formular uma interpretação, ou seja, uma associação livre em relação à fala repetitiva e padronizada do paciente. A escuta supõe, portanto, a possibilidade de uma livre associação na repetição, ou seja, supõe que na fala repetitiva e padronizada do paciente possam ser encontrados fenômenos e artefatos separados e distantes passíveis de uma articulação, uma ligação.

Pensar, nesse sentido, não significa encontrar um sentido proporcionando uma compreensão. A articulação, a ligação que caracteriza a interpretação psicanalítica não supõe um sentido. O pensamento entendido como livre associação não é nem hermenêutico nem compreensivo. Ele é simplesmente livre associativo.

A livre associação possui a finalidade precípua de juntar, aproximar fenômenos e artefatos separados e distantes presentes na fala repetitiva e padronizada do paciente. Esses fenômenos e artefatos, por sua vez, não estão na fala do paciente explícitos, mas sim obscuros, e a arte da interpretação deve permitir que o paciente reconheça certa estranha familiaridade entre a livre associação e a repetição de sua fala. Há, na interpretação, a possibilidade de uma clareza denominada insight ou descoberta. Esta se manifesta quando ocorre uma ligação entre a repetição e os elementos obscuros aí contidos, que são revelados, desencobertos com a interpretação. Em outras palavras, a interpretação, assim entendida, não pode ignorar o pressuposto segundo o qual o explícito contém o implícito, ou seja, que a fala repetitiva e padronizada é uma defesa intrapsíquica se opondo à livre associação. Só há livre associação se houver repetição.

Além disso, quando ocorre descoberta, ela é vivida como verdade. Dito de outra forma, a associação livre possibilita articulações que desencobrem aquilo que estava obscuro e implícito na repetição. A verdade é, assim, evanescente. Não possui um caráter permanente. Revelando o obscuro, a verdade é um convite à livre associação e ao reencontro com a repetição. Uma vez revelada, a verdade dá 
início à repetição e se constitui, assim, numa fonte para a resistência à livre associação. É essa dinâmica contraditória que permite o interminável processo de pensamento no humano.

A livre associação como modelo para o pensamento está, portanto, presente tanto em Vannevar Bush quanto em Freud. O que é diferente é a suposição a respeito da possibilidade da associação. Bush e Brito supõem que quantidade de informação e possibilidade de comunicação - características essenciais da internet - são condições necessárias e suficientes para o pensamento. Freud, por sua vez, introduzindo a compulsão à repetição, apresenta um limite intransponível para a livre associação. Porém, mais do que isso, revela o caráter contraditório do pensar. Não basta a web e a internet para se pensar. É necessário, também, enfrentar a repetição que impede e possibilita a livre associação.

A repetição impedindo o pensamento é, portanto, aquilo que deve ser levado em consideração para que o pensamento ocorra. Não é possível combater a repetição tomando-a superficialmente, pois é na própria repetição que residem os elementos da livre associação. Não é inteligente exigir tanto de cientistas quanto de "pensadores" uma permanente originalidade de pensamento. A ciência é feita de inúmeras repetições e algumas descobertas, ou seja, algumas livres associações surgindo como verdades. Pensar requer um trabalho de escuta, ou melhor, um trabalho voltado para o reconhecimento de fenômenos e artefatos implícitos na repetição encontrando-se obscuros, separados e distantes, como no exemplo de Eratóstenes lembrado por Brito. 